\title{
Assessing Land Use and Land Cover Change in the Volta Grande Do Xingu (Pará - Brazil) Between 2000 and 2017
}

\section{Alynne Almeida Affonso ( $\square$ alynne.affonso@usp.br)}

University of Sao Paulo Institute of Energy and Environment: Universidade de Sao Paulo Instituto de

Energia e Ambiente https://orcid.org/0000-0002-2646-3922

Silvia Sayuri Mandai

University of Sao Paulo Institute of Energy and Environment: Universidade de Sao Paulo Instituto de Energia e Ambiente

Tatiana Pineda Portella

University of Sao Paulo Institute of Biosciences: Universidade de Sao Paulo Instituto de Biociencias

Carlos Henrique Grohmann

University of Sao Paulo Institute of Energy and Environment: Universidade de Sao Paulo Instituto de

Energia e Ambiente

José Alberto Quintanilha

University of Sao Paulo Institute of Energy and Environment: Universidade de Sao Paulo Instituto de Energia e Ambiente

\section{Original Research}

Keywords: Amazon, Belo Monte, Land Cover, Remote sensing, Land Use, Xingu river

Posted Date: February 18th, 2021

DOl: https://doi.org/10.21203/rs.3.rs-172975/v1

License: (c) (i) This work is licensed under a Creative Commons Attribution 4.0 International License.

Read Full License 


\section{Abstract}

This study aims to assess the land use and land cover change through the use of three pixel-based methods of image classification (Mahalanobis, Maximum Likelihood, and Minimum Distance) in the region of Volta Grande do Xingu (Brazilian Amazon), under influence of the Belo Monte hydroelectric power plant. Different pixel-based classification methods were performed on Landsat 7 and 8 multispectral products from the years 2000 and 2017, using a 2008 map as the ground truth image. The accuracies of the classifications were compared, and land use change analyses were performed in the different scenarios. The main impacts regarding land use and land cover change were from forest to agro pasture, from non-river to river upstream the Xingu river, and from river to non-river in the south of the Volta Grande do Xingu, resulting in rocks exposure.

\section{Introduction}

The Amazon Forest is a megadiverse biome, distributed within nine countries, mostly in Brazil. This biome has been through great pressure under anthropogenic activities in the past decade (Rosa et al. 2017). Although one of the most important impacts for the continuing-decline of tropical forests globally are agriculture-related (covering approximately $50 \%$ of the tropical biome) (Lerner et al. 2013), impacts related to hydroelectric dams are expressive. In the Brazilian Amazon the construction of hydroelectric dams has increased since the 1990s due to its large water system and potential for energy generation through its rivers, driven by government plans aiming energy security, economic growth and industrialization (Moretto et al. 2012; Prado et al. 2016; Timpe and Kaplan 2017).

Impacts related to the loss of ecological niches in areas upstream and downstream of dams in large tropical rivers cannot be neglected. According to Winemiller et al. (2016), these impacts have been assessed belatedly, affecting their recovering capabilities. That is the case of the Belo Monte dam in the Volta Grande do Xingu area (Calvi et al. 2020), where alterations caused by the dams of the Belo Monte hydroelectric power plant resulted in changes in habitats and biomes. As a consequence, there was loss of endemic species, since anthropogenic impacts unbalance geological and geomorphological processes and ecological functions, compromising the ways of life of traditional communities that directly depend on the flow of the Xingu river and its flood pulses.

It is a global trend to manage ecosystems for goods or services and not realizing its consequential tradeoffs. Such negligence results in water shortages, species loss, declining on fish catches and loss of key habitats (Revenga 2005). In the case of the Xingu river, to build the plant reservoirs and dams, a vast area of vegetation has been directly deforested or lost due to the flooding (estimates of $516 \mathrm{~km}^{2}$ - Leme Engenharia 2009; Jiang et al. 2018). Also, there was an important reduction in the Xingu river water flow downstream, generating substantial changes in fishing and land use for agriculture, including threats to the secular ways of life of indigenous people and traditional communities living in the area, whether in demarcated lands or not (e.g., Pezutti et al. 2018; Calvi et al. 2020). 
The construction of large hydroelectric power plants in the northern area of Brazil has been criticized for its low economic return in contrast to their large environmental and social impacts (Calvi et al. 2020). Many activities are developed in the area where the hydroelectric power plant is implemented, motivated mainly by the economic investment in the region, in the energy supply to be explored and in the large number of workers who move and fix residency in the area. Such actions might induce forest disturbance with consequential fragmentation of the environment, resulting on a mixture of land cover pieces of distinct classes, sizes and shapes (Rosa et al. 2017). Hence, there are land use and land cover changes (Ferreira et al. 2015). Land use is associated with anthropic interactions with land surfaces (i.e., modifications to the socioeconomic organization of the region), and land cover, with biophysical characteristics of the Earth's surface (Martinez and Mollicone 2012; Souza Jr et al. 2020). Thus, land use and land cover changes allow the comparison between two or more scenarios of a target area.

The attraction of workers and the resettlement of families affected by these developing projects generate population and settlement growth and consequently, an increase in deforestation, resulting in important changes in the ecosystem balance (Rosa et al. 2017). The land use change be exacerbated to a larger degree when the plant construction is finished, and workers need to find other forms of subsistence, such as extraction and agriculture (Fearnside 2008). Indeed, most of the deforested area in the Amazon is used for agriculture, mainly cattle ranching (Rosa et al. 2017). For example, an indirect impact assessment of the Belo Monte plant predicted an increase of 4,000 to $5,000 \mathrm{~km}^{2}$ in the loss of surrounding forest by 2031 (Barreto et al. 2011). Indirect deforestation that occurs around large hydroelectric dams can also lead to loss of terrestrial biodiversity (Fearnside 2005), increase the incidence of diseases (Patz et al. 2004), and reduction of rainfall (Nepstad et al. 2008), generating a decrease in water discharge from rivers and, consequently, a reduction in the hydroelectric power of the plant (Lees et al. 2016).

Therefore, in order to better understand the impacts of large hydroelectric power plants, it is important to increase and improve knowledge about land use and land cover changes, applying technologies that monitor forest landscapes. This is essential due to the high conservation and preservation values of the Amazon Forest biome.

Technologies such as remote sensing and Geographic Information Systems (GIS) facilitates observations on the surface of the earth, since satellite-derived information is a digital computer-based source of information, allowing the combination of physical, biological and socio-economic data to analyze landscapes and ecosystems, enabling to assess changes and impacts (Revenga 2005). Remote sensing images have been widely used as data sources to classify land cover, and to assess how different types of activities have affected natural landscapes over time (Silva et al. 2008; Jiang et al. 2018). Moreover, the classification of images has been used to analyze the accuracy of areas covered by water related to the installation of hydroelectric power plants (Cochrane et al. 2017).

A widely used method for the classification of the land use and land cover is the technique known as pixel-based image analysis, as reported by MapBiomas project, which analyzes the historical land use and land cover dynamics in the six Brazilian biomes (Souza Jr et al. 2020). In the pixel-based 
classification method each pixel of the image is compared with classes of interest. This method is able to provide proper results in several applications, although some studies have shown that not all the spatial information is entirely available, mainly in heterogeneous areas (Jiang et al. 2018).

This study seeks to analyze the land use and land cover change of the Volta Grande do Xingu area and compare the applications of three pixel-based methods (Mahalanobis, Maximum Likelihood, and Minimum Distance). The classifications aim to identify direct and indirect alterations in land use and land cover that might be related to the construction of Belo Monte hydroelectric power plant, using Landsat 7 and 8 imagery.

\section{Materials And Methods}

Study area

The construction of Belo Monte hydroelectric began in 2001 and was completed in 2016. The watershed of the Xingu river is located in the Brazilian states of Pará and Mato Grosso, but the Volta Grande do Xingu is totally in Pará, in the region of the Altamira municipality. The main dam of Belo Monte, which resulted in the Xingu reservoir, is $40 \mathrm{~km}$ downstream of the municipality of Altamira, the largest Brazilian municipality (Pará, 2011) and the main urban area in the vicinity of Belo Monte (Fig. 1). The Brazilian Institute of Environment and Natural Resources (IBAMA) is the environmental agency responsible for the licensing of the developing project.

The Amazon is mainly covered by evergreen forest, wetlands and surface water, and the main land uses of the biome are cattle ranching, agriculture, mining, logging, non-timber forestry production and uses related to occupation processes, as road building (Rosa et al. 2017; Souza Jr et al. 2020). For the study area, most of the land cover and land use include primary forest, secondary forest, agriculture (such as cocoa plantations and other kinds of crops), pasture, exposed soil, and alluvial forests under the influence of flood pulses (Jiang et al. 2018). In this region, there are large blocks of rock in the Xingu river channel with associated vegetation, mainly downstream of its encounter with the Bacajá river and close to its encounter with the Iriri river (Fig. 1) (Leme Engenharia 2009).

The region has a humid tropical climate (equatorial), characterized by high average air temperatures (24$27^{\circ} \mathrm{C}$ ) and high rainfall rates (monthly average over $60 \mathrm{~mm}$ in all months of the year). Associated with these environmental conditions, the chosen area to place the dam is extremely rich and diverse in fauna and flora, with about 174 species of fish, 440 species of birds, 259 species of mammals, as well as endemic and endangered species (Costa et al. 2012). The local economy is based on familiar agriculture, and has riverside agriculture and traditional extractive activities, such as rubber and Brazil nut.

Data Set

To evaluate the applicability of the digital processing and image classification method, this study analyzed Landsat 7 (Fig. 1b) and Landsat 8 (Fig. 1C) multispectral products, relative to the years 2000 
and 2017 respectively, both downloaded from the USGS Landsat Image Gallery platform with spatial resolution of 30 meters. In addition to that, for the training stage, a 2008 raster image describing the land use and land cover was used as ground truth data (Fig. 1a). According to the Environmental Impact Study (Leme Engenharia 2009), the ground truth image was elaborated from shapefiles obtained from IBAMA and IBGE databases, from remote sensing imagery analysis (Landsat images from 2001 and 2002) and field trips that occurred during the licensing process.

Image Classification

The pixel-based classification was performed on Envi 5.5.3. Three supervised classification methods were used for the analysis.

- Minimum Distance Classifier: this method characterizes each class by its mean reflectance in each band from the training site with unknown pixels assigned to the class with the nearest mean value.

- Maximum Likelihood Classification: in this method, the probability density function calculated for a specific training site signature with a pixel designated to the most likely class is calculated, based on a comparison of the subsequent probability that belongs to each of the signatures being considered.

- Mahalanobis Distance Classification: similar to the Maximum Likelihood Classification, is a direction-induced distance classifier where probability statistics is used for each class, but assuming that all covariances are equal. It is also a faster method.

The post classification tools "Sieve Classes" and "Majority/Minority Analysis" were applied to reduce classification misunderstandings on Envi 5.5.3. The first one was used to soften isolate pixels issues, and the other one was applied to change spurious pixels within a large single class to that specific class. After that, confusion matrices using ground truth regions of interest (ROI) were calculated. Ground truth ROls are labeled reference areas sampled on a digitized map, used as reference from a prior knowledge acquired preferably during a field trip to the area of study (Baraldi et al. 2005). This method pairs ROls with the classes of a classified image to show what percentage of ROI pixels were or not in the resulting class (Harris Geospatial n.d.).

Accuracy Assessment

An accuracy evaluation from the classification procedures performed on the Landsat images from years 2000 and 2017 was carried out in order to determine their quality metrics. For this, confusion matrices were calculated aiming to statistically compare the accuracy of the methods in relation to the reference classes obtained by the ground truth image. Quantitative accuracy assessment of maps relies on the comparison of the area represented on the map against reference information for the same site. Sample comparison strategies are used to estimate the accuracy of the maps (Baraldi et al. 2005).

The report generated when a confusion matrix is calculated contains: 
- Overall Accuracy: calculated by summing the number of reliable classified values divided by the total number of values.

- Kappa coefficient: measures how equivalent classification and truth values are. A kappa value of 1 represents a perfect match, while a value of 0 represents no equivalence.

- Errors of Commission: are the fraction of values that were predicted to be in a class but do not belong to that class (false positives).

- Errors of Omission: are the fraction of values that belong to a class but were predicted to be in a different class (false negatives).

- Producer Accuracy: a measure of the probability that a value in a given class was classified properly.

- User Accuracy: a measure of the probability that a value predicted to be in a certain class really is that class.

Detecting land cover change

The Post-Classification Comparison, which is a change detection analysis, was performed using ESRI ArcMap version 10.4. Studies have shown that this method offers good accuracy in representing changes in land use (Prenzel and Treitz 2006; Virk and King 2007).

For this study, maps generated for Mahalanobis, Minimum Distance Classifier, and Maximum Likelihood Classification methods from years 2000 and 2017 were analyzed and the results were crosstabulated comparing each pixel. Then, maps regarding land cover change were generated for the forest/non-forest and for river/non-river class categories. The direction of land use change was tabulated and represented as graphics, in which land use change was estimated using ten classes: pasture to forest, rock to forest, river to forest, forest to pasture, forest to rock, forest to river, river to pasture, river to rock, pasture to river, and rock to river.

Moreover, to verify differences in the imagery bands, a spectral analysis was performed.

\section{Results And Discussion}

The three pixel-based classifiers, Mahalanobis, Minimum Distance and Maximum Likelihood, showed similar values of overall accuracy and kappa coefficient (Table 1), indicating that the present classifications for the study area are very close to the expected classification. For the year 2000, Maximum Likelihood Classification was slightly more accurate than the others $(76,58 \%$ and 0,6032 for overall accuracy and kappa coefficient respectively). However, for 2017, Mahalanobis and Minimum Distance had the same indexes, being slightly more accurate than Maximum Likelihood classification ( $79,76 \%$ and 0,6514 for overall accuracy and kappa coefficient respectively).

The visual classifications of the three pixel-based methods are represented in figures 2 and 3 for years 2000 and 2017 respectively, while table 2 shows a summary of parameters calculated for river, forest, agro-pasture, and rock classes. The river class had higher user accuracies for Maximum Likelihood than 
the other methods for 2000 and 2017 (75,1\% and 94,63\% respectively). However, producer accuracies were higher for Mahalanobis and Minimum Distance, which is a context similar to what is observed in figures 2 and 3.

Visually, forest and agro pasture classes had similar results (Fig. 2 and 3). For forest class, the user and producer accuracies were very similar with higher values for 2017. Likewise, agro pasture class showed similar user and producer accuracies for year 2000, with larger variations for 2017. Moreover, pixels were classified more as clouds by the Maximum Likelihood method in comparison to others for 2000 (Fig. 2).

At last, Mahalanobis and Minimum Distance had similar user and producer accuracies for years 2000 and 2017 for rock class, in which producer accuracies were lower than the user ones. Nevertheless, Maximum Likelihood classification showed that this method is more likely to classify a pixel as rock than river (Fig. 2 and 3). Furthermore, Maximum Likelihood classification had homogeneous values of accuracy, except for producer accuracy for 2017.

In summary, despite the similarities among the three pixel-based methods, Mahalanobis and Minimum Distance were slightly more adequate to distinguish river and rock classes (Fig. 4 and 5).

Land cover change

Figures 4 and 5 show the land cover change for the Volta Grande do Xingu. Downstream the Xingu river, the main alteration is the conversion from river to non-river areas, while, upstream and in a channel area northward, there was an increase in the river area (non-river to river class), associated with the construction of the reservoir by flooding forest areas (Fig. 5).

Regarding the forest and non-forest transitions, the preponderant class is forest to non-forest areas from the year 2000 to 2017 (Fig. 4), due to the land flooding for the reservoir construction and the expansion and installation of other economic activities triggered by the power plant construction (Fig. 6). The main example is the conversion from forest to agro pasture, as shown by all three classification methods (Fig. 6). Nevertheless, the land cover change also indicates that a few agro pasture areas have been converted to forest, mainly in the north of the study area, similar to what is observed in Figure 4 (non-forest to forest class). Another substantial transition was downstream the Xingu river, where an extensive area of the Xingu river channel was replaced by rocks (Fig. 6).

Spectral Mixture

A spectral analysis was performed for the Volta Grande do Xingu classification, and a mixture of spectral signatures was observed. For example, for river, rocks and forest classes in the year 2000 (Fig. 7), the reflectance was almost identical in the blue, green and red bands, as well as clouds and agropasture have some overlapping. For the year 2017, although agropasture and rocks are well separated from other classes, these two are superimposed at the visible band. The same happens in forest and river spectral signatures (Fig. 7), exhibiting a pattern of two spectral signature clusters in the visible band. 
Although the two clusters can be separated between them in both cases, the overlapping between classes could not be avoided. It justifies part of the incoherence observed in the confusion matrix, since the similarities in spectral reflectance among classes can reduce classification separability.

\section{Discussion}

Hydropower has been the main source of renewable energy around the world, especially for developing countries (Atkins 2020). The same situation is observed for Brazil in the Amazon region with the construction of large hydroelectric power plants, such as Belo Monte in Pará and Jirau and Santo Antônio in Rondônia (Moretto et al. 2012; Moran et al. 2018). Based on the hydroelectric potential in Amazon (Eletrobrás 1994) and the need to assess and monitor the impacts on this biome, the improvement of remote sensing techniques and methods is pertinent to avoid and minimize impacts for future projects. This study revealed land use and land cover change caused by the construction of the Belo Monte Hydroelectric Power Plant in the Volta Grande do Xingu using three pixel-based methods with similar accuracy indexes (Mahalanobis, Minimum Distance Classifier, and Maximum Likelihood). Here, we discuss some direct and indirect impacts concerning transformations in the river and forest classes.

One of the main impacts was the conversion from river to non-river areas in the south of the Volta Grande do Xingu, observed in the results from the three classification methods. River fragmentation or its interruption impacts the hydrological cycle, harming freshwater ecosystems and species. The disconnection of rivers from their floodplains and wetlands caused by dams modifies the flow velocity, impacting the migratory patterns of fish species and the composition of the riparian habitat, alters sediment and nutrient loads and might cause loss of biodiversity and fishery resources (Ravenga 2005). For the Volta Grande do Xingu area, the river course deviation altered the rocks' exposure in this region, as observed in the class "river to non-river" (Fig. 5). However, this exposure can pose a threat to the biodiversity adapted and associated with rock vegetation (in Portuguese, vegetação dos pedrais), which is dependent on flood pulses, i.e., periodic river flow pulsing that supports ecosystem productivity (Junk et al. 2014). Consequently, change in annual flood pulses may alter river connectivity, like for sediments, nutrients, and biota, affecting agriculture (disappearance or reduction of land production), forestry, and other activities dependent from this hydrologic flow (Vainer and Araújo 1992; Bortoleto 2001; Zhouri and Oliveira 2007; Bermann 2007; Junk et al. 2014; Timpe and Kaplan 2017).

Also associated with river connectivity, studies have shown that water reservoirs that keep the dam are responsible for reducing the biodiversity, being specifically harmful to migratory fish species (Agostinho et al. 2004). Such panorama results in the dismantling of territories preexisting before the dam. As a consequence, the river cover change has affected the fishery (see review from Moran et al. 2018). Based on the Environmental Impact Statement, to assure the continuity of life quality for local populations and aquatic ecosystems, with connectivity during dry seasons (e.g., navigation), a minimum amount of water downstream the river was defined as $100 \mathrm{~km}$ length, measured along the Xingu river (Leme Engenharia 2009). 
When redirecting the water flow through small channels, due to the interruption of the water flux to build the river dam, two indigenous reservations were badly affected: Paquiçamba and Arara da Volta Grande, as predicted by the Environmental Impact Statement (Leme Engenharia 2009). This region had its water flow reduced to a minimum, depriving indigenous people and riverside dwellers from traditional habits, such as fishing, their main source of subsistence, and navigation, since the river is an important method of transportation (De Sousa Jr and Reid 2010; Santos and Hernandez 2009).

Indeed, one of the major criticisms on the construction of the Belo Monte hydroelectric power plant is related to a claim from traditional populations. They were not considered as directly affected by the dam on the Environmental Impact Statement elaborated as a requirement to obtain the environmental licenses to install the power plant (Eletrobrás 1994). Thus, during public consultations, indigenous populations were not consulted in the same way as the populations living in directly affected areas, such as the flooded areas (The Economist 2013).

In contrast, an increase in the river area was observed upstream the Xingu river and in a channel northward Volta Grande do rio Xingu, as seen in the non-river to river class (Fig. 5). The results show that the installation of the Belo Monte dam changed significantly the river upstream with alterations on the magnitude, frequency, duration, timing, and river flow, resulting in biophysical and social effects. The main reason is the conversion from lotic to lentic flow, affecting water quality and biodiversity, such as fish connectivity (Moran et al. 2018). Furthermore, the reservoir's construction causes deforestation and consequently greenhouse gases emissions from floodplain forest degradation.

Based on the Environmental Impact Statement of Belo Monte, made previously to the construction of the developing project, the construction of Belo Monte reservoir was expected to remove $42 \%$ of the Xingu river and $24 \%$ of the forests of the region (Leme Engenharia 2009). Similarly, this study shows both transformations in land cover: river to non-river downstream the Xingu river (previously discussed), and from forest to non-forest near the reservoir, since local and regional processes affect deforestation and land-use changes, and direct conversions consequential from this are forest to pasture (Gollnow et al. 2018). To build the dam, deforestation (forest to non-forest class) was required for other associated activities, such as roads, accommodation/workers houses, construction sites, plant structures, and equipment assembly (Leme Engenharia 2009).

Although policies of expansion of conservation units have been shown to be important tools on reducing deforestation rates (Rosa 2017), the presence of protected areas and indigenous areas occupying more than half of the Xingu watershed did not prevent human pressures on the region. Some instances are soy and pasture expansion, the extraction of wood, and the human occupation along the roads BR-163 and Transamazônica, which fragmented the habitats and altered the ecosystems nearby (Leme Engenharia 2009; Stabile et al. 2020). This corroborated the well reported fact that in the Brazilian Amazon, fragmentation of landscape has been directly related to anthropogenic activities, such as road building, logging, cleaning land for agriculture and wildfire (Rosa 2017). The mentioned points are also influencing indirectly the Volta Grande do Xingu. 
As mentioned, this study shows a vast forest loss around the Belo Monte power plant, caused mainly for the conversion from forest to agro pasture. The increase in infrastructure works attracted by the Belo Monte power plant is also responsible for improving transport access to more remote areas (Fearnside 2019), which may have contributed to the conversion of forest to agro pasture observed in this study. Indeed, it is well known that deforestation patterns are associated with road access, especially in areas of agrarian projects (Soler and Verburg 2010). In addition, the region also received economic incentives for the development of activities related to cattle ranching (Calvi et al. 2019), resulting in $116 \%$ growth from 2000 to 2017 (IBGE 2020).

A positive relationship between population growth and deforestation has been reported for several regions of the Amazon, resulting also in disordered land use (Lawrence et al. 2002; Prate et al. 2008; Barreto et al. 2011). The city of Altamira had a large population growth between 2000 and 2017, i.e., from 78,000 people to more than 111,000 inhabitants (IBGE 2020). Much of this growth was due to the construction of the Belo Monte power plant, which attracted people from more than 1,500 Brazilian cities to work in the region (Miranda Neto 2017).

The forest change was expected to alter the extractive resources, since it might cause alterations to the aboveground biomass dynamics, triggering loss of species richness and abundance (Rosa et al. 2015), which impact indigenous people, such as Paquiçamba, Arara da Volta Grande do Xingu and Juruna from $\mathrm{km} 17$ due to the proximity to the enterprise and its consequences (Leme Engenharia 2009). Another study about the indirect deforestation caused by the Belo Monte power plant also predicted an increase in deforestation in this region related to population growth and agriculture (Barreto et al. 2011). These authors recommended some mitigation measures, such as intensifying environmental monitoring and the creation of protected areas, aiming to avoid or reduce deforestation (Barreto et al. 2011).

Previous studies reported that road patterns may provide an indication of the actors of land use change (Soler and Verbug 2010). One way to analyze human activity is the accuracy assessment of the forest area change using remote sensing techniques (FAO, 2016), because land use and land cover change may be associated with the establishment of developing projects. In this context, a challenge for accuracy levels in tropical forest areas has been the atmospheric conditions resulting in many clouds, which can cause a confusion between cloud shadows and the river, as observed in the spectral mixture (Fig. 7). Furthermore, the humidity and heat may result in saturated pixels, while fog can cause noise in the images, reducing the accuracy of the analysis. Indeed, in Altamira, high average air temperatures (24$\left.27^{\circ} \mathrm{C}\right)$ and high rainfall rate $(1,680 \mathrm{~mm}$ per year) are observed. This way, the accuracy could be improved with field trips to the Volta Grande do Xingu as a future validation process.

Another alternative to improve the classification accuracy could be the use of semantic segmentation with deep learning to associate segmentation and object-based analysis (e.g., Nogueira et al. 2015). Furthermore, future studies could explore more classes of land use and land cover in the Amazon biome to better understand the impacts of dams in a megadiverse area. 


\section{Conclusions}

The area of Volta Grande do Xingu was chosen to analyze the land use and land cover change from 2000 (when the Belo Monte dam was not installed) to 2017 (when the dam construction was finished). In all cases, the main conversions concerning land use and land cover were: from forest to agro pasture, from forest/agro pasture to river upstream the Xingu river, and from river to non-river in the south of the Volta Grande do Xingu, resulting in rock exposure. These impacts were associated mainly with the construction of the reservoir, the river deviation to install the main dam of the hydroelectric, and the agro pasture expansion.

Since geospatial data and information facilitates the analysis and assessment of land cover changes and the understanding of temporal dynamics and location-specific processes and agents impacting landscapes is crucial in this process, remote sensing techniques have been employed in many areas of environmental management, such as evaluating the alterations in land use and land change after the installation of hydroelectric power plants. The pixel-based Mahalanobis, Minimum Distance, and Maximum Likelihood methods showed many similarities among the indexes of accuracy analyzed by the present study, however Mahalanobis and Minimum Distance were considered more adequate to distinguish river and rock classes.

Specifically for the study area, the analysis in the Volta Grande do Xingu had some challenges due to the presence of high temperatures, humidity and clouds most of the year. Likewise, tropical forests impose challenges related to spectral overlapping of targets and classes, as well as spectral mixture affecting the analysis significantly. To overcome these challenges, field trips to the sites might be conducted to validate the ground truth data, aiming to improve the classification algorithm inductive learning application

As there are large and small hydroelectric power plants planned to be constructed in the Amazon, it is important to understand the land use and land cover change associated with these activities, as well as to verify good methods to analyze these transitions. Therefore, the present study validates the use of pixel-based Mahalanobis and Minimum Distance methods to analyze land use and land cover change in tropical forest in future analyzes.

\section{Declarations}

\section{Funding}

This study was financed in part by the Coordenação de Aperfeiçoamento de Pessoal de Nível Superior Brazil (CAPES) - Finance Code 001 (Authors 1, 2 and 3).

Author 4 is a research fellow of Brazil's National Council of Scientific and Technological Development (CNPq, grants \#423481/2018-5 and \#304413/2018-6). 
The authors have no conflicts of interest to declare that are relevant to the content of this article.

\section{Availability of data and material}

All data generated or analyzed during this study are included in this published article.

\section{Code Availability}

Nothing to declare.

\section{Author's contributions}

Author 1, 2 and 3 conceived of the presented idea. Author 1 performed the image processing, geostatistic calculations and the production of maps. Author 2 developed the discussion with support from Authors 1 and 3. Author 3 performed the land cover and land use quantification and analysis. Authors 4 and 5 supervised all the findings of this work and encouraged the research. All authors discussed the results and contributed to the final manuscript.

\section{ACKNOWLEDGEMENT}

The authors thank the Institute of Energy and Environment and the Graduate Program in Environmental Science, University of São Paulo, Brazil and Mr. The authors acknowledge Mr. Kyle Flavin, for the revision of the text. Acknowledgements are extended to the Editor-in-Chief, the Associate Editor, and the anonymous reviewers for their criticism and suggestions, which helped to improve this paper. CHG is a research fellow of Brazil's National Council of Scientific and Technological Development (CNPq, grants \#423481/2018-5 and \#304413/2018-6). This study was financed in part by CAPES Brasil - Finance Code 001.

\section{References}

Agostinho, A,A, Pelice, F.M., Gomes, L.C. (2008) Dams and the fish fauna of the Neotropical region: Impacts and management related to diversity and fisheries. Brazilian Journal of Biology, 68:1119-1132. doi: 10.1590/S1519-69842008000500019

Atkins, E. (2020) Contesting the 'greening' of hydropower in the Brazilian Amazon. Political Geography, 80:102179. doi: 10.1016/j.polgeo.2020.102179

Baraldi, A., Bruzzone, L., Blonda, P. (2005). Quality assessment of classification and cluster map without ground truth knowledge. IEEE Transactions on Geoscience and Remote Sensing, 43:857-873. doi: 10.1109/TGRS.2004.843074 
Barreto, P., Brandão, A., Martins, H., Silva, D., Souza, C., Sales, Jr. M. et al. (2011). Risco de desmatamento associado à hidrelétrica de Belo Monte. Belém, Brazil: Instituto do Homem e Meio Ambiente da Amazônia (IMAZON), 98 pp. http://www.imazon.org.br/publicacoes/livros/risco-de-desmatamento-associado-ahidreletricade-belo-monte/at_download/file. Accessed 26 August 2020.

Bermann, C. (2007). Impasses and controversies of hydroelectricity. Estudos avançados 21:139-153.

Bortoleto, E.M. (2001). A Implantação de grandes hidrelétricas: Desenvolvimento, discurso e impactos. Geografares, 2:53-62. https://www.periodicos.ufes.br/index.php/geografares/article/view/1140/853. Acessed 06 June 2020.

Calvi, M.F. (2019). (Re) Organização Produtiva e mudanças na paisagem sob influência da hidrelétrica de Belo Monte. Phd thesis. Universidade Estadual de Campinas, Campinas, SP.

Calvi, M.F., Moran, E.F., Silva, R.F.B., Batistella, M. (2020). The construction of the Belo Monte dam in the Brazilian Amazon and its consequences on regional rural labor. Land use policy, 90:104327-1-10432612. doi: $10.1016 /$ j.landusepol.2019.104327

Cochrane, S.M.V., Matricardi, E.A.T., Numata, I., Lefebvre, P.A. (2017). Landsat-based analysis of mega dam flooding impacts in the Amazon compared to associated environmental impact assessments: Upper Madeira River example 2006-2015. Remote Sensing Application Society Environment, 7:1-8. https://doi.org/10.1016/j.rsase.2017.04.005

Sousa, W.C.J., Reid, J. (2010). Uncertainties in Amazon hydropower development: Risk scenarios and environmental issues around the Belo Monte dam. Water Alternatives, 3:249-268.

Eletrobrás, Centrais Elétricas Brasileiras S/A (2009). Aproveitamento Hidrelétrico Belo Monte: Estudo de Impacto Ambiental. Eletrobrás, Rio de Janeiro.

FAO, Food and Agriculture Organization of the United Nations (2016). Map Accuracy Assessment and Area Estimation: A Practical Guide. Rome, Brazil: FAO, 69 p. Available at: <http://www.fao.org/3/ai5601e.pdf>

Fearnside, P.M. (2005). Deforestation in Brazilian Amazonia: History, rates, and consequences. Conservation Biology, 19:680-688. https://doi.org/10.1111/j.1523-1739.2005.00697.x

Fearnside, P.M. (2008). The roles and movements of actors in the deforestation of Brazilian Amazonia. Ecology and Society, 13:23. Available at http://www.ecologyandsociety.org/vol13/iss1/art23./ Acessed May 2020

Fearnside, et al. (2019). Hidrelétricas na Amazônia brasileira: Questões ambientais e sociais. pp. 7-22. In: P.M. Fearnside (ed.) Hidrelétricas na Amazônia: Impactos Ambientais e Sociais na Tomada de Decisões sobre Grandes Obras. Vol. 3. Editora do INPA, Manaus pp. 148. 
Ferreira, M.D.P., Coelho, A.B. (2015). Desmatamento recente nos estados da Amazônia Legal: uma análise da contribuição dos preços agrícolas e das políticas governamentais. Revista de Ecologia e Sociologia Rura,l 53:093-108. doi: https://doi.org/10.1590/1234-56781806-9479005301005

Gollnow, F., Göpel, J., Hissa, L.B.V., Schaldach, R., Lakes, T. (2018). Scenarios of land-use change in a deforestation corridor in the Brazilian Amazon: combining two scales of analysis. Regional Environmental Change, 18:143-159. doi: 10.1007/s10113-017-1129-1

Harris Geospatial. Calculate Confusion Matrices. (ND)

https://www.harrisgeospatial.com/docs/CalculatingConfusionMatrices.html. Accessed 23 June 2020.

IBGE, Instituto Brasileiro de Geografia e Estatística. Pesquisa da Pecuária Municipal. https://sidra.ibge.gov.br/tabela/3939. Acessed August 2020

Jiang, X., Lu, D., Moran, E., et al. (2018). Examining impacts of the Belo Monte hydroelectric dam construction on land-cover changes using multitemporal Landsat imagery. Applied Geography, 97:35-47. doi: 10.1016/j.apgeog.2018.05.019

Junk, W.J., Piedade, M.T.F., Lourival, R., et al. (2014). Brazilian wetlands: Their definition, delineation, and classification for research, sustainable management, and protection. Aquatic Conservation: Marine and Freshwater Ecosystems, 24:5-22. doi: 10.1002/aqc.2386

Laurance, W.F., Albernazm A.K.M., Schroth, G., Fearnside, P.M., Bergen, S., et al. (2002). Predictors of deforestation in the Brazilian Amazon. Journal of Biogeography, 29:737-748. doi:

https://doi.org/10.1046/j.1365-2699.2002.00721.x

Lees, A.C., Peres, C.A., Fearnside, P.M., et a.I (2016). Hydropower and the future of Amazonian biodiversity. Biodiversity Conservation, 25:451-466. doi: 10.1007/s10531-016-1072-3

Leme Engenharia (2009). Aproveitamento Hidrelétrico Belo Monte - Relatório de Impacto Ambiental.

Lerner, A.M., Rudel, T.H., Schneider, L.C., McGroddy, M., Burbano, D.V., Mena, C.F. (2015). The spontaneous emergence of silvo-pastoral landscapes in the Ecuadorian Amazon: patterns and processes. Regional Environmental Change, 15:1421-1431. doi 10.1007/s10113-014-0699-4

Martínez, S., Mollicone, D. (2012). From Land Cover to Land Use: A Methodology to Assess Land Use from Remote Sensing Data. Remote Sensing, 4:1024-1045. doi: 10.3390/rs4041024

Miranda Neto, J.Q. (2017). Os nexos de re-estruturação da cidade e da rede urbana: as implicações espaciais da instalação da Usina de Belo Monte em Altamira-PA e em sua região de influência. Formação, 24: 65-95.

Moran, E.F., Lopez, M.C., Moore, N., et al. (2018). Sustainable hydropower in the 21 st century. Proceedings of the National Acaddemy of Sciences of the United States of America, 115:11891-11898. doi: 
Moretto, E.M., Gomes, C.S., Roquett,i D.R., Jordão, C.D.O. (2012). Histórico, tendências e perspectivas no planejamento espacial de usinas hidrelétricas brasileiras: A antiga e atual fronteira amazônica. Ambiente e Sociedade, 15:141-164. doi: 10.1590/S1414-753X2012000300009

Nogueira K., Schwartz W.R., dos Santos J.A. (2015) Coffee Crop Recognition Using Multi-scale Convolutional Neural Networks. In: Pardo A., Kittler J. (eds) Progress in Pattern Recognition, Image Analysis, Computer Vision, and Applications. CIARP 2015.Lecture Notes in Computer Science, vol 9423. Springer, Cham. doi: 10.1007/978-3-319-25751-8_9

Pará. (2011). Altamira: Estatística municipal. http://iah.iec.pa.gov.br/iah/fulltext/georeferenciamento/altamira.pdf. Acessed August 2020.

Patz, J.A., Daszak, P., Tabor, G.M., et al. (2004). Unhealthy landscapes: Policy recommendations on land use change and infectious disease emergence. Environmental Health Perspectives, 112:1092-1098. doi: 10.1289/ehp.6877

Pezutti, J., Carneiro, C., Mantovanelli, T., Garzón, B.R. (2018). Xingu, o rio que pulsa em nós. Monitoramento independente para registro de impactos da UHE Belo Monte no território e no modo de vida do povo Juruna (Yudjá) da Volta Grande do Xingu. $1^{\text {a }}$ Edição. Instituto Socioambiental, pp 46.

Prado, F.A., Athayde, S., Mossa, J., et al. (2016). How much is enough? An integrated examination of energy security, economic growth and climate change related to hydropower expansion in Brazil. Renewable and Sustainable Energy Reviews, 53:1132-1136. doi: 10.1016/j.rser.2015.09.050

Prates, R.C. (2008). O desmatamento desigual na Amazônia brasileira: sua evolução, suas causas e conseqüências sobre o bem-estar. Universidade de São Paulo, Piracicaba, 2008.

Prenzel, B.G., Treitz, P. (2006). Spectral and spatial filtering for enhanced thematic change analysis of remotely sensed data. International Journal of Remote Sensing, 27: 835-854. Doi 10.1080/01431160500300321

Ravenga, C. (2005). Developing indicators of ecosystem condition using geographic information systems and remote sensing. Regional Environmental Change, 5:205-214. doi 10.1007/s10113-004-0085-8.

Rosa, I.M.D., Gabriel, C., Carreiras, J.M.B. (2017). Spatial and temporal dimensions of landscape fragmentation across the Brazilian Amazon. Regional Environmental Change, 17:1687-1699. doi 10.1007/s10113-017-1120-x.

Santos, S.B.M.; Hernandez, F.M. (2009). Painel de Especialistas: Análise Crítica do Estudo de Impacto Ambiental do Aproveitamento Hidrelétrico de Belo Monte. Belém, Brazil: Painel de Especialistas sobre a Hidrelétrica de Belo Monte, pp 230. 
Silva, M.P.S., Camara, G., Escada, M.I.S., Modesto de Souza, R.C. (2008). Remote-sensing image mining: Detecting agents of land-use change in tropical forest areas. International Journal of Remote Sensing, 29:4803-4822. doi: 10.1080/01431160801950634

Soler, .LS., Verburg, P.H. (2010). Combining remote sensing and household level data for regional scale analysis of land cover change in the Brazilian Amazon. Regional Environmental Change, 10:371-386. doi 10.1007/s10113-009-0107-7

Souza, C.M., Shimbo, J.Z., Rosa, M.R., et al. (2020). Reconstructing three decades of land use and land cover changes in brazilian biomes with landsat archive and earth engine. Remote Sensing, 12(17). doi: 10.3390/RS12172735

Stabile, M.C.C., Guimarães, A.L., Silva, D.S., et al. (2020). Solving Brazil's land use puzzle: Increasing production and slowing Amazon deforestation. Land Use Policy, 91:104362. doi:

10.1016/j.landusepol.2019.104362

The Economist. (2013). Dams in the Amazon: the rights and wrongs of Belo Monte. Available: http://www.economist.com/news/americas/21577073-having-spent-heavily-make-worldsthird-biggesthydroelectric-project-greener-brazil. Accessed 26 July 2020.

Timpe, K., Kaplan, D. (2017). The changing hydrology of a dammed Amazon. Science Advances, 3:1-14. doi: $10.1126 /$ sciadv.1700611

Vainer, C.B., Araujo, F.G.B. (1992). Grandes projetos hidrelétricos e desenvolvimento regional. CEDI, Rio de Janeiro.

Virk, R., Kiing, D. (2007). Comparison techniques for forest change mapping using Landsatdata in Karnataka, Geocarto International, 21:49-57.

Winemiller, K.O., Mclntyre, P.B., Castello, L., Fluet-Chouinard, E., Giarizzp, T., Nam, S., Saénz, L. (2016). Balancing hydropower and biodiversity in the Amazon, Congo, and Mekong. Science, 351: 128-129. doi: 10.1126/science.aac7082

Zhouri, A., Oliveira,, R. (2007). Desenvolvimento, conflitos sociais e violência no Brasil rural: o caso das usinas hidrelétricas. Ambiente e Sociedade, 10:119-35.

\section{Tables}

Table 1: Overall accuracy and kappa coefficient for supervised classification methods.

\begin{tabular}{|c|c|c|c|c|}
\hline \multirow{2}{*}{ Supervised classification method } & \multicolumn{2}{|c|}{2000} & \multicolumn{2}{c|}{2017} \\
\cline { 2 - 5 } & Overall Accuracy & Kappa Coefficient & Overall Accuracy & Kappa Coefficient \\
\hline Minimum Distance Classifier & $75,56 \%$ & 0,578 & $79,76 \%$ & 0,6514 \\
\hline Maximum Likelihood Classification & $76,58 \%$ & 0,6032 & $74,95 \%$ & 0,6016 \\
\hline Mahalanobis Distance Classification & $75,56 \%$ & 0,578 & $79,76 \%$ & 0,6514 \\
\hline
\end{tabular}


Table 2: Commission and omission terrors and Producer and User accuracies for supervised classification methods (Mahalanobis Distance, Maximum Likelihood and Minimum Distance).

\begin{tabular}{|c|c|c|c|c|c|c|c|c|}
\hline \multirow[b]{2}{*}{ Class } & \multicolumn{4}{|c|}{2000} & \multicolumn{4}{|c|}{2017} \\
\hline & Comission & Omission & $\begin{array}{c}\text { Producer accuracy } \\
\text { (\%) }\end{array}$ & $\begin{array}{c}\text { User accuracy } \\
(\%)\end{array}$ & Comission & Omission & $\begin{array}{c}\text { Producer accuracy } \\
\text { (\%) }\end{array}$ & $\begin{array}{c}\text { User accuracy } \\
(\%)\end{array}$ \\
\hline \multicolumn{9}{|c|}{ Mahalanobis Distance } \\
\hline River & 32,38 & 9,19 & 90,81 & 67,62 & 25,25 & 10,98 & 89,02 & 74,75 \\
\hline Forest & 14,88 & 10,51 & 89,49 & 85,12 & 14,04 & 9,78 & 90,22 & 85,96 \\
\hline $\begin{array}{c}\text { Agro } \\
\text { pasture }\end{array}$ & 38,54 & 66,94 & 33,06 & 61,46 & 34,28 & 54,45 & 45,55 & 65,72 \\
\hline Rocks & 50,45 & 92,83 & 7,17 & 49,55 & 42,71 & 63,17 & 36,83 & 57,29 \\
\hline \multicolumn{9}{|c|}{ Maximum Likelihood } \\
\hline River & 24,9 & 16,81 & 83,19 & 75,1 & 5,37 & 45 & 55 & 94,63 \\
\hline Forest & 13,43 & 11,64 & 88,36 & 86,57 & 9,55 & 15,74 & 84,26 & 90,45 \\
\hline $\begin{array}{c}\text { Agro } \\
\text { pasture }\end{array}$ & 31,81 & 64,87 & 35,13 & 68,19 & 44,74 & 37,64 & 62,36 & 55,26 \\
\hline Rocks & 65,17 & 61,35 & 38,65 & 34,83 & 62,99 & 19,54 & 80,46 & 37,01 \\
\hline \multicolumn{9}{|c|}{ Minimum Distance } \\
\hline River & 32,17 & 9,53 & 90,47 & 67,83 & 24,41 & 10,96 & 89,04 & 75,59 \\
\hline Forest & 14,85 & 10,73 & 89,27 & 85,15 & 14,56 & 9,48 & 90,52 & 85,44 \\
\hline $\begin{array}{c}\text { Agro } \\
\text { pasture }\end{array}$ & 38,54 & 66,97 & 33,03 & 61,46 & 47,8 & 61,97 & 38,03 & 52,2 \\
\hline Rocks & 50,45 & 92,87 & 7,13 & 49,55 & 44,53 & 67,54 & 32,46 & 55,47 \\
\hline
\end{tabular}

Figures 


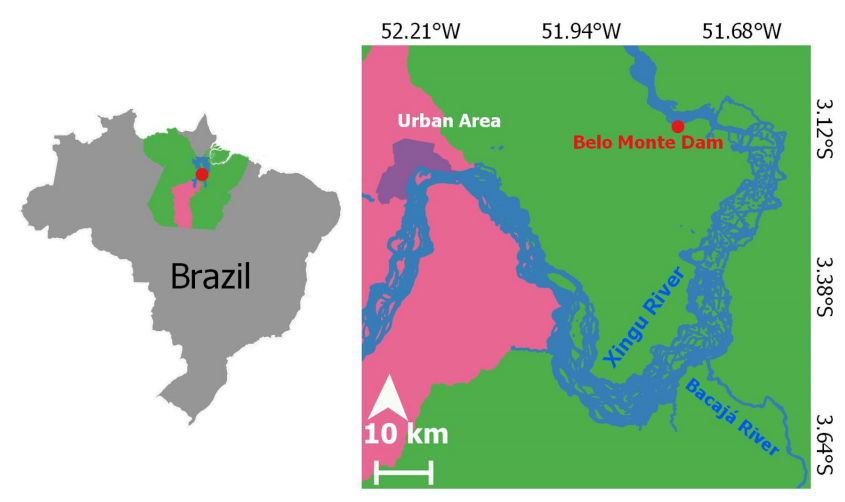

- Belo Monte

Xingu River

Altamira Municipality

Para State
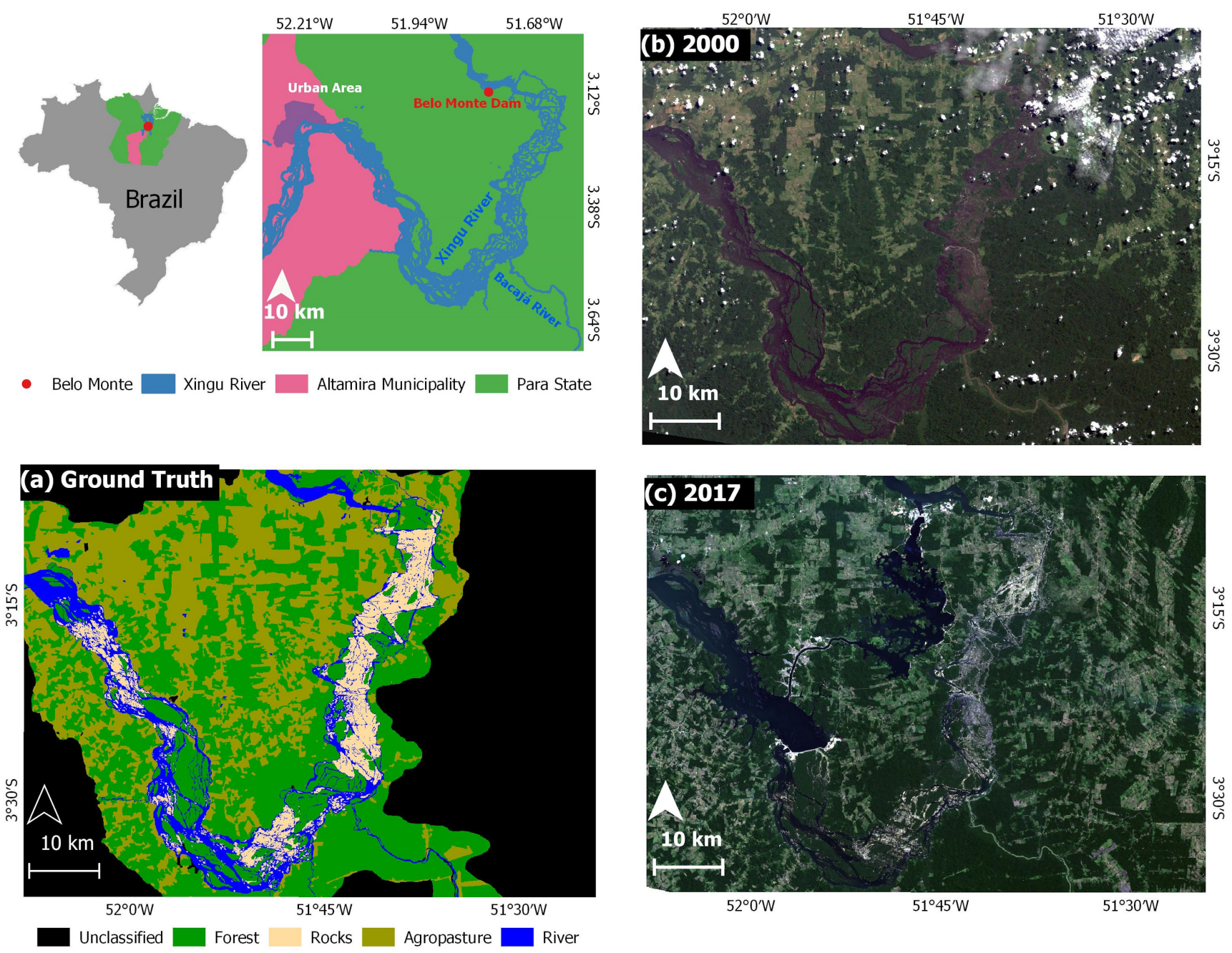

\section{Figure 1}

The study area is part of the direct influence area of Belo Monte hydroelectric power plant on the Volta Grande do Xingu area. (a) Ground Truth dataset based on the data available on the EIA of the Belo Monte dam (b) Landsat 7 image from the year 2000 (c) Landsat 8 image from the year 2017 

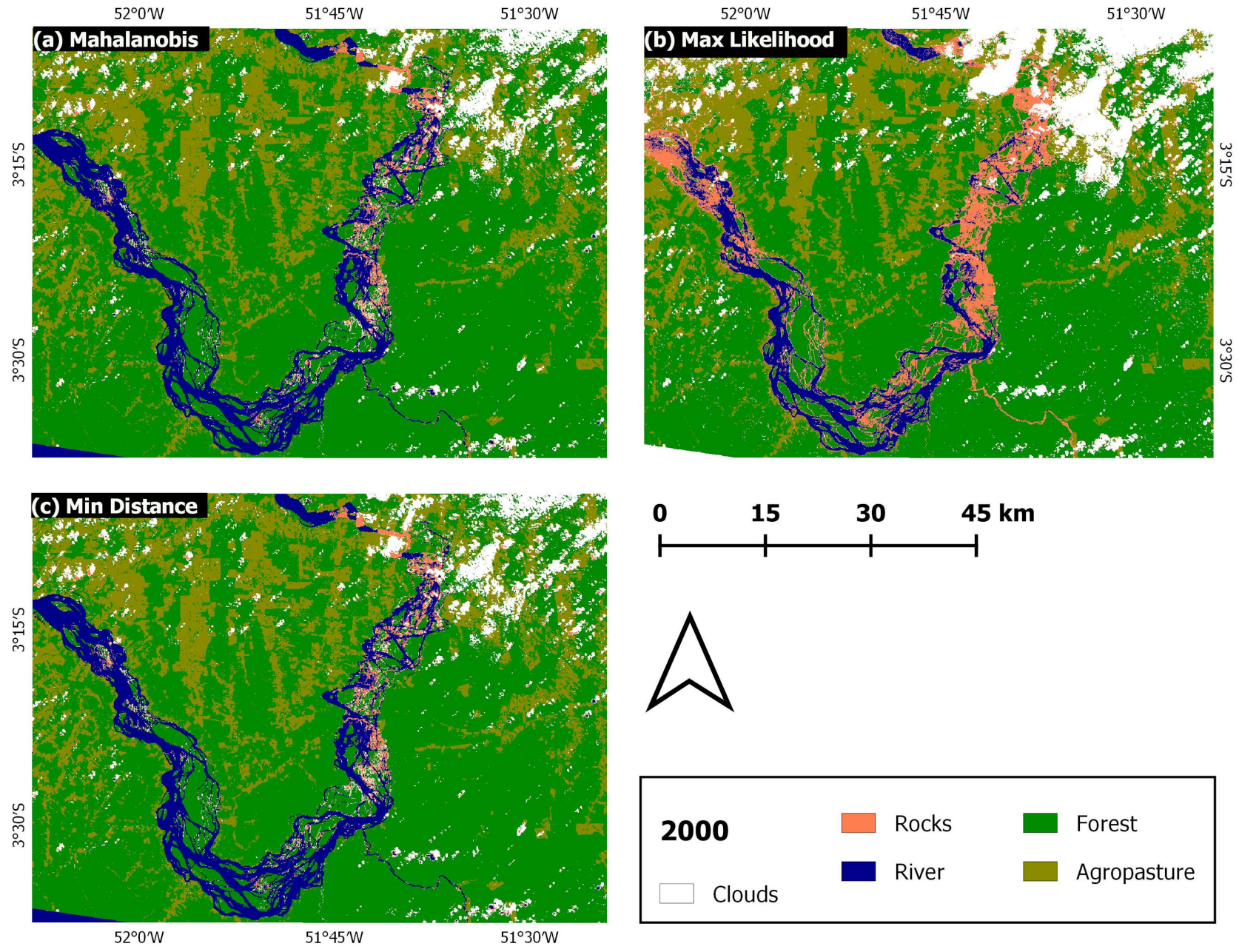

\section{Figure 2}

Pixel-based classification from Mahalanobis (a), Maximum Likelihood (b), and Minimum Distance (c) classifications for the year 2000 

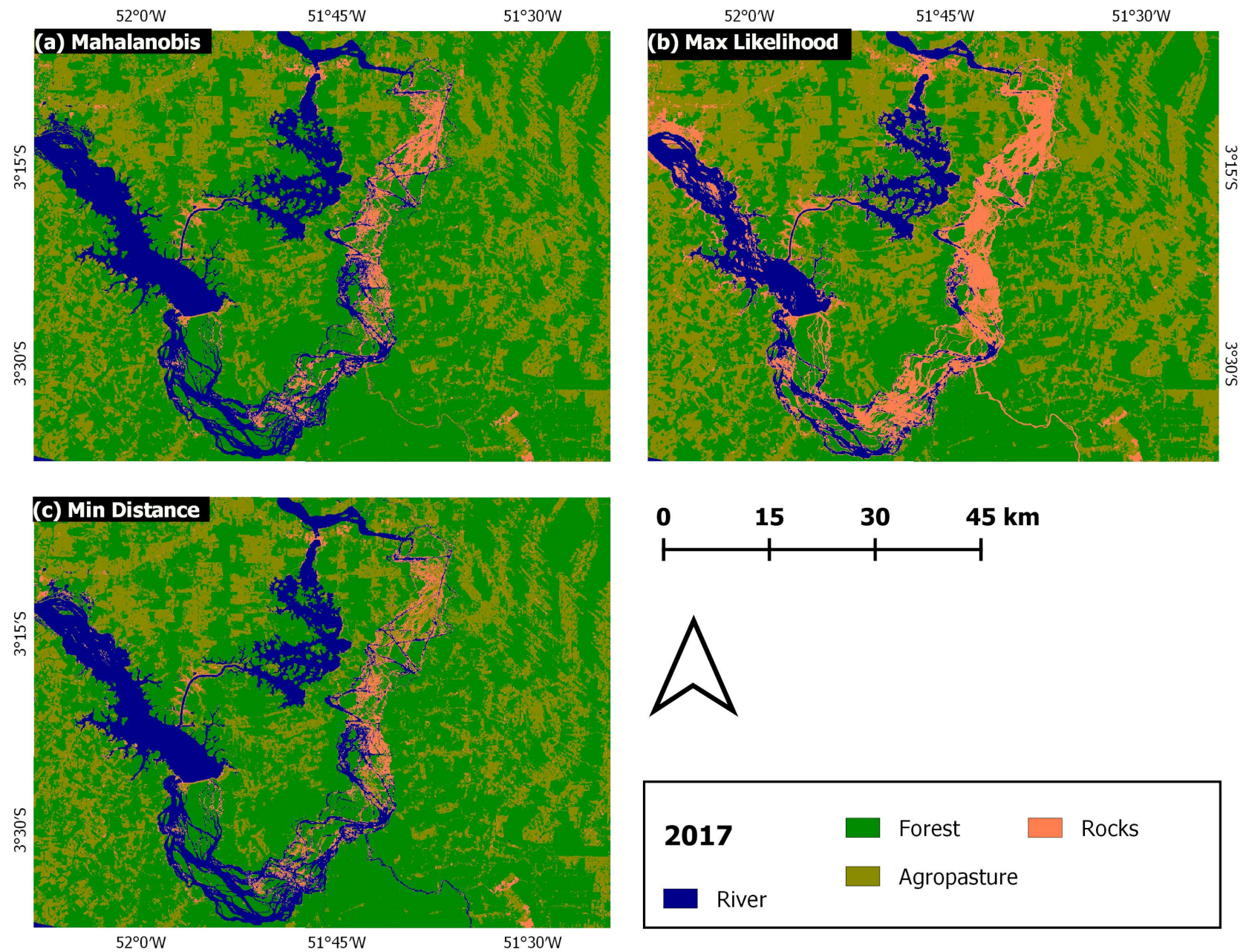

\section{Figure 3}

Pixel-based classification from Mahalanobis (a), Maximum Likelihood (b), and Minimum Distance (c) classifications for the year 2017 

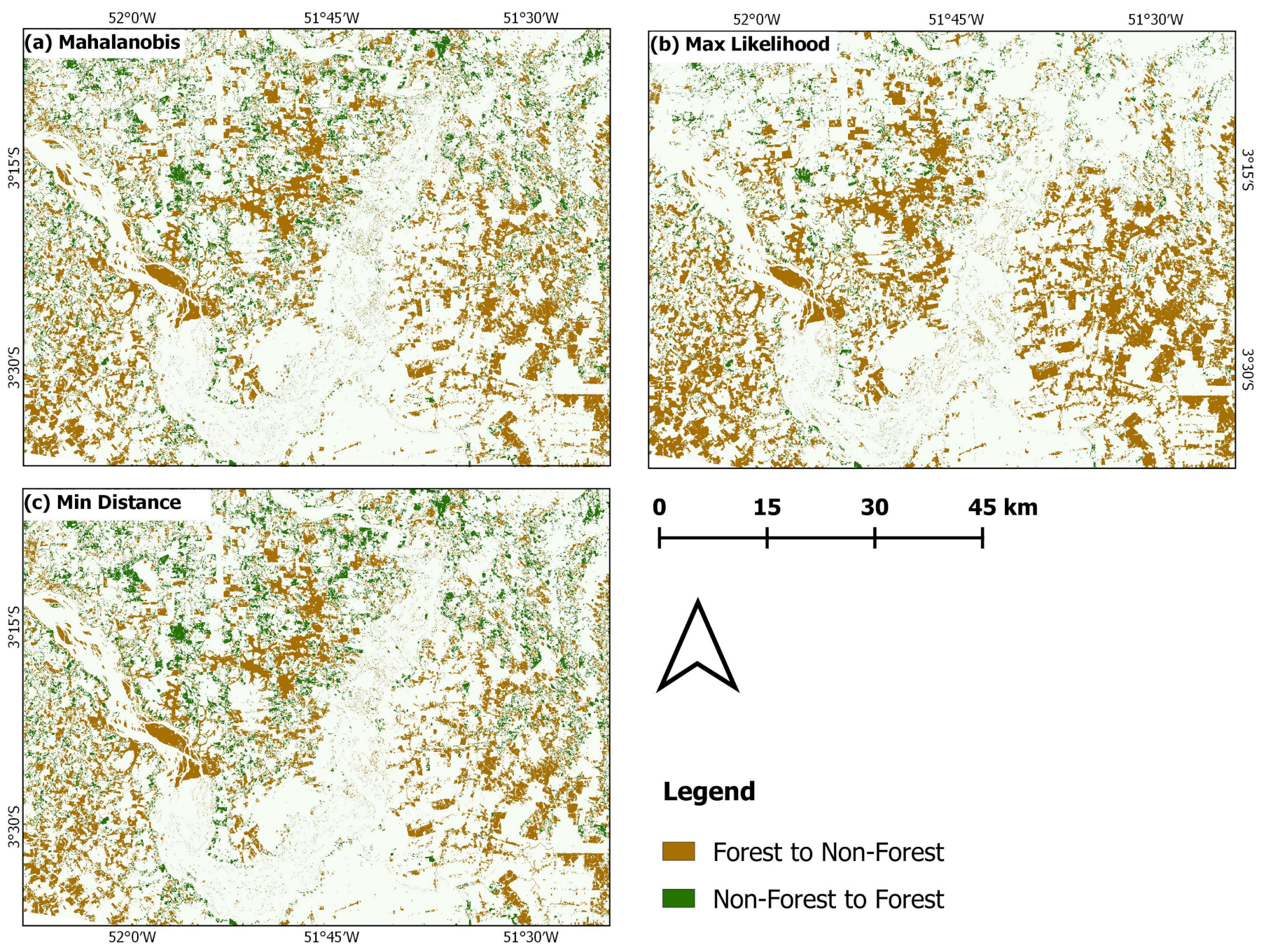

Forest to Non-Forest
Non-Forest to Forest

\section{Figure 4}

Land cover change for forest and non-forest transitions from 2000 to 2017, resulted from Mahalanobis (a), Maximum Likelihood (b) and Minimum Distance (c) classifications 

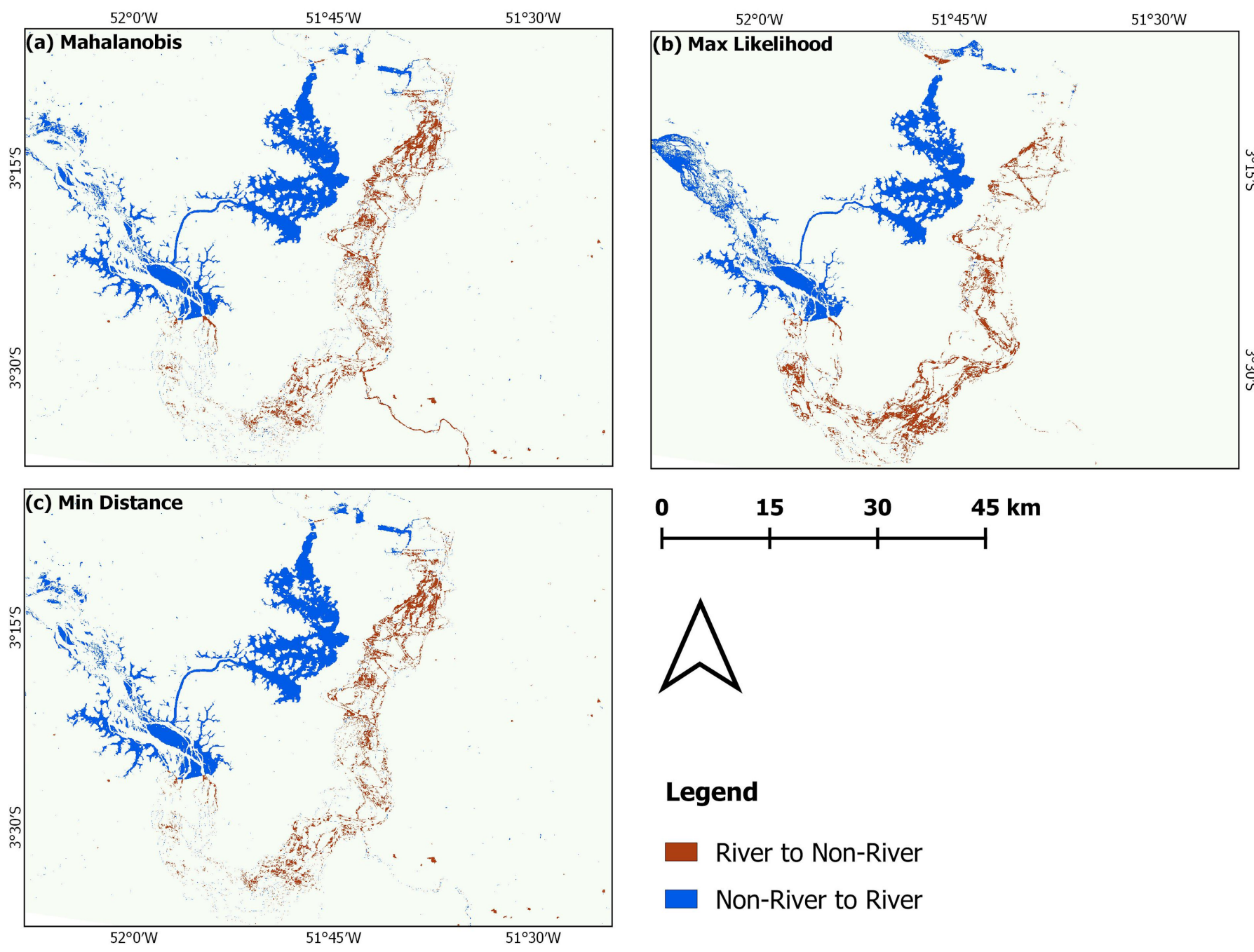

\section{Legend}

River to Non-River

Non-River to River

\section{Figure 5}

Land cover change for river and non-river transitions from 2000 to 2017, resulted from Mahalanobis (a), Maximum Likelihood (b) and Minimum Distance (c) classifications 
(a) Non-forest to forest

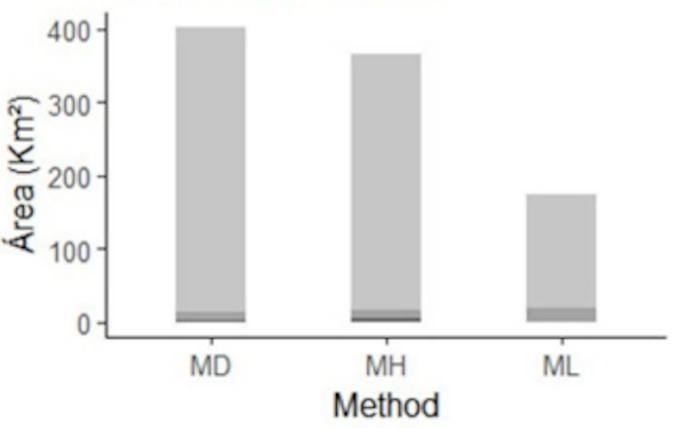

(c) Water to non-water

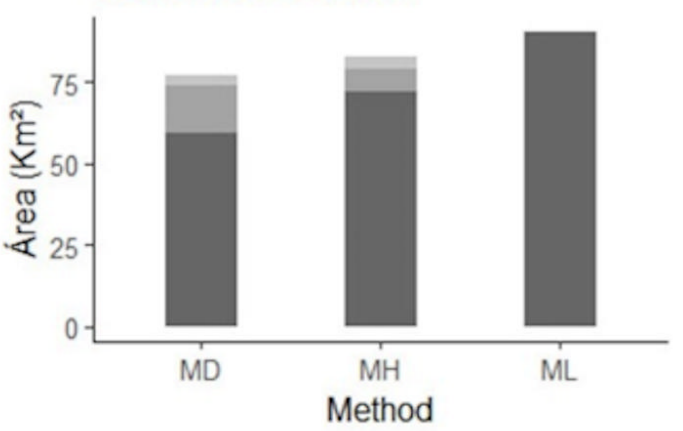

(b) Forest to non-forest

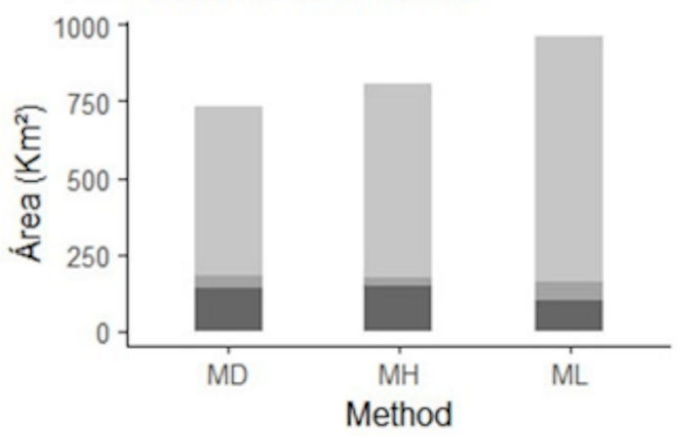

LCC trajectory

fo-pa

fo-ro fo-wa

(d) Non-water to water

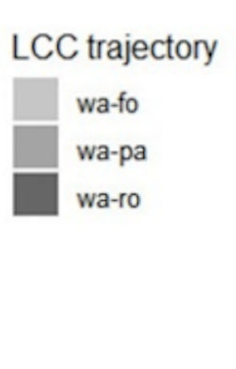

\section{Figure 6}

Land use and land cover change from 2000 to 2017 using Minimum Distance (MD), Mahalanobis Distance $(\mathrm{MH})$ and Maximum Likelihood (ML) classifiers. Trajectories: pasture to forest (pa-fo), rock to forest (ro-fo), river to forest (ri-fo), forest to pasture (fo-pa), forest to rock (fo-ro), forest to river (fo-ri), river to pasture (ri-pa), river to rock (ri-ro), pasture to river (pa-ri), and rock to river (ro-ri)

(a) 2000

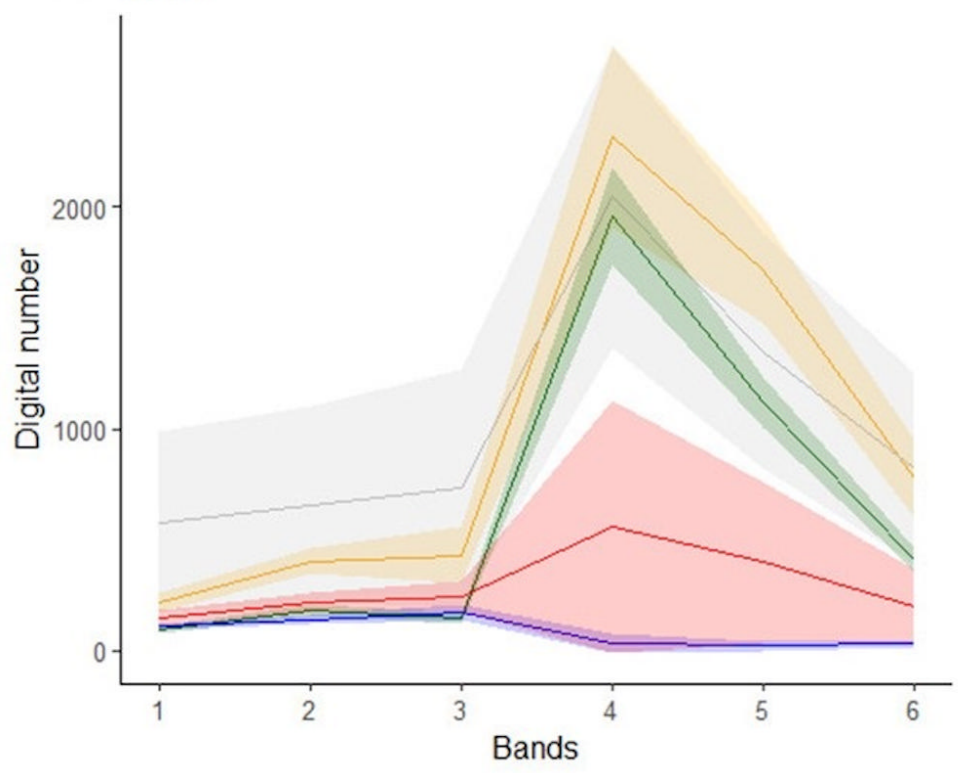

Agropasture - Clouds - Forest - River - Rocks (b) 2017

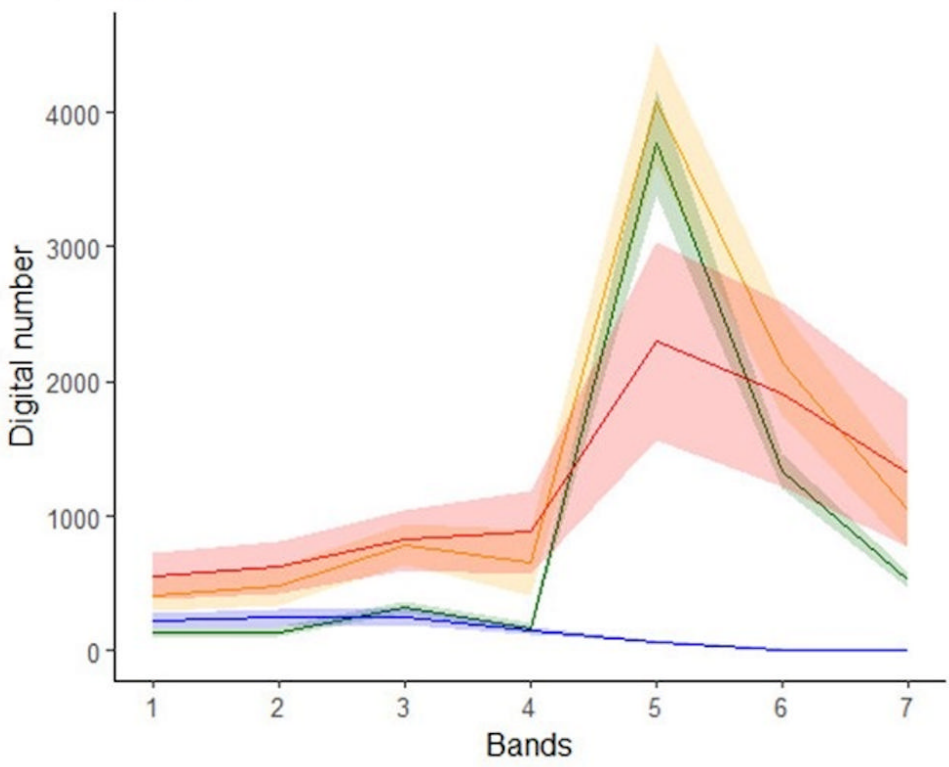

Agropasture - Forest - River - Rocks 
Figure 7

Spectral mixture regarding the pixels of the images of Volta Grande do Xingu from 2000 (a) and 2017 (b) 